\title{
宿題報告
}

\section{3. 造血の分子機構と臨床}

元吉 和夫

Key words：M-CSF, サイトカイン・ネットワーク, 娃娠性白血球增加症, 二重盲検比較試験

\section{はじめに}

ヒト末梢血中には白血球，赤血球それに血小 板があり，それらは骨䯣において多能性造血幹 細胞が增殖しながら分化することによって産生 される．多能性造血幹細胞の存在をはじめて明 らかにし，実験血液学の端緒を開いたのがTill とMcCullochである。彼らは1961年に致死量 （約 9Gy）の放射線照射したマウスに，同系統の マウスの骨髄細胞を尾静脈より注射 (骨䯣移植) すると，マウスが死なずに生き残ることを見い 出した，骨䯣細胞を注射されなかったマウスは すべて死亡した．放射線照射後 12〜14 日目に， マウスの造血器官である脾臓の表面に肉眼でも わかる隆起が認められ，彼らはこの隆起を脾コ ロニーと呼び，また骨髄細胞はバラバラにして マウスに注射したのであるから，脾コロニーの 数は注射した骨髄細胞の中の脾コロニー形成細 胞colony-forming unit-spleen (CFU-S) の数を反 映していると考えた。この脾コロニーは赤芽球 の他, 好中球, 単球, 巨核球, さらにはBリンパ 球まで含み増殖能が高く, 多能性造血幹細胞hematopoietic stem cells (HSC) 由来と考えられた。

1960 年代の中頃, 骨骨道細胞をin vitroで培盖す る方法（コロニー形成法）が開発された。この

\section{もとよし かず㧍：防衛医科大学校第三内科}

方法を用いて赤血球系前駆細胞 (erythroid progenitor) であるburst-forming unit erythroid (BFU-E) やcolony-forming unit erythroid(CFU-E), 好中球/単球系前駆細胞であるCFU granulocytemacrophage (CFU-GM)，巨核球一血小板系前駆 細胞であるCFU-megakaryocyte (CFU-Meg), 好中球前駆細胞であるCFU-granulocyte（CFUG), それに単球前駆細胞であるCFU-macrophage (CFU-M) などの各系列の前駆細胞が次々に発見 された。

HSCはまずリンパ系幹細胞 (lymphoid stem cell) と骨髄系幹細胞 (myeloid stem cell) に分

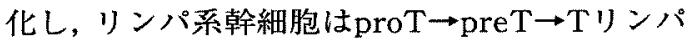

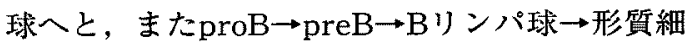
胞人と分化する。一方骨䯣系幹細胞はBFU-E, CFU-GM，それにCFU-Megへと分化し，ついで CFU-GMはCFU-GとCFU-Mへと分化する.すな わち赤血球はBFU-E $\rightarrow$ CFU-E $\rightarrow$ 赤芽球 $\rightarrow$ 網赤血 球 $\rightarrow$ 赤血球という経路で，好中球はCFU-GM $\rightarrow$ CFU-G $\rightarrow$ 骨䯣芽球 $\rightarrow$ 前骨䯣球 $\rightarrow$ 骨䯣球 $\rightarrow$ 後骨䯣 球 $\rightarrow$ 桿状核球 $\rightarrow$ 分節核球という経路で，単球・ マクロファージはCFU-GM $\rightarrow$ CFU-M $\rightarrow$ 単芽球 $\rightarrow$

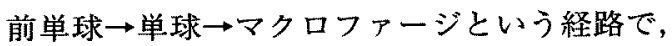
また血小板はCFU-Meg $\rightarrow$ 巨核球 $\rightarrow$ 血小板という 経路で産生される。このように骨䯣中には多能 性造血幹細胞, 造血前駆細胞, 未熟血球それに 成熟血球といった異なった分化段階の細胞群が 混在している. 
筆者らが研究を開始した 1970 年代の中頃には, (1)生体が細菌感染症に罹患し好中球が増加する 前に単球が増加することや, (2)周期性好中球減 少症の患者では好中球減少期には単球が増加し ていること, などの臨床的観察から造血細胞は ばらばらに産生されるのではなく, 液性因子に よって産生が調節されているのではないかと考 えられていた。

筆者らは造血を調節しているサイトカインに 着目して，まずヒト尿中にin vitroコロニー法に おいて骨髄細胞からマクロファージコロニーの 形成を刺激する因子macrophage colony-stimulating factor (M-CSF) を発見し1〜3), 純化および 遺伝子クローニングに成功した4.5)。また好中球 増加症を示す癌患者の癌組織をヌードマウスの 皮下に接種して, 癌組織から好中球産生を促進 する因子granulocyte CSF (G-CSF) が産生され ていることをin vitroおよびin vivoで証明し た6,7). ついで筆者らは遺伝子組換え型M-CSF を用いたin vitro, in vivo, およびex vivoの実験を 行い, 造血がM-CSFを中心としたサイトカイン . ネットワーク機構で調節されていることを明ら かとした。さらにM-CSFが造血刺激活性以外に も, 絨毛細胞分化促進活性, 破骨細胞分化促進 活性,さらに脂質代謝促進活性などをもった多 機能性因子であることを発見した8).

またM-CSFの造血刺激活性を臨床応用するた めに, 骨髄移植後の患者, 急性骨髄性白血病の 患者, それに卵巣癌の患者において, 大規模二 重盲検比較試験を実施し, M-CSFが癌化学療法 後の白血球減少症や血小板減少症に対して有効 であることを証明した。

\section{M-CSFの発見と遺伝子クローニング}

1978 年筆者らはヒト尿中にin vitroコロニー形 成法において，骨䯣細胞からマクロファージコ ロニー形成を刺激する因子を発見してcolonystimulating factor from human urine (CSF-HU)

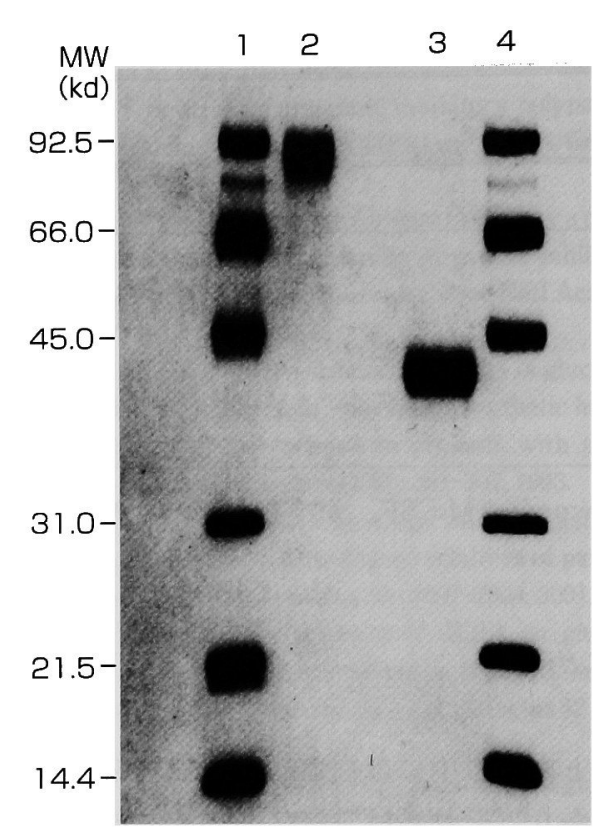

図 1. 純化M-CSFのポリアクリルアミドゲル電気 泳動

レーン 1 と 2 は非還元下, レーン 3 と 4 は還元下 の電気泳動で,レーン 1 と 4 は分子量マーカー,レー ン2と 3 は純化M-CSFを電気泳動した. 純化MCSFは非還元下 (レーン2) では 85kD, 還元下 (レーン 3)では 43kDのそれぞれ 1 本のバンドとし て泳動したので,M-CSFが分子量43kDのサブユニッ トの木モ2量体であることがわかった.

と命名した ${ }^{1 \sim 3)}$. ヒト尿濃縮液を原材料として DEAE-cellulose, phenyl-sepharose, hydroxyapatite, chromatofocusing, reversed-phase highperformance liquid chromatography (HPLC) を 用いて精製した. 原材料中にはCSF-HUの他に, CSF-HUの活性を阻害する物質が大量に共存して おり, 当初精製は困難を極めたが, DEAE-cellulose カラムによってCSF-HUと阻害物質を分離するこ とができることを発見したことが，純化に成功 した最大の要因であうた.最終精製標品は $2 \times 10^{8}$ units/mg蛋白の比活性をもった分子量 $85 \mathrm{kD}$ の糖 蛋白質であり, 分子量 $43 \mathrm{kD}$ のブユニットのホ モ 2 量体であった (図 1) 1,4,5).

1987 年筆者らはGenetics Institute社(Boston, 


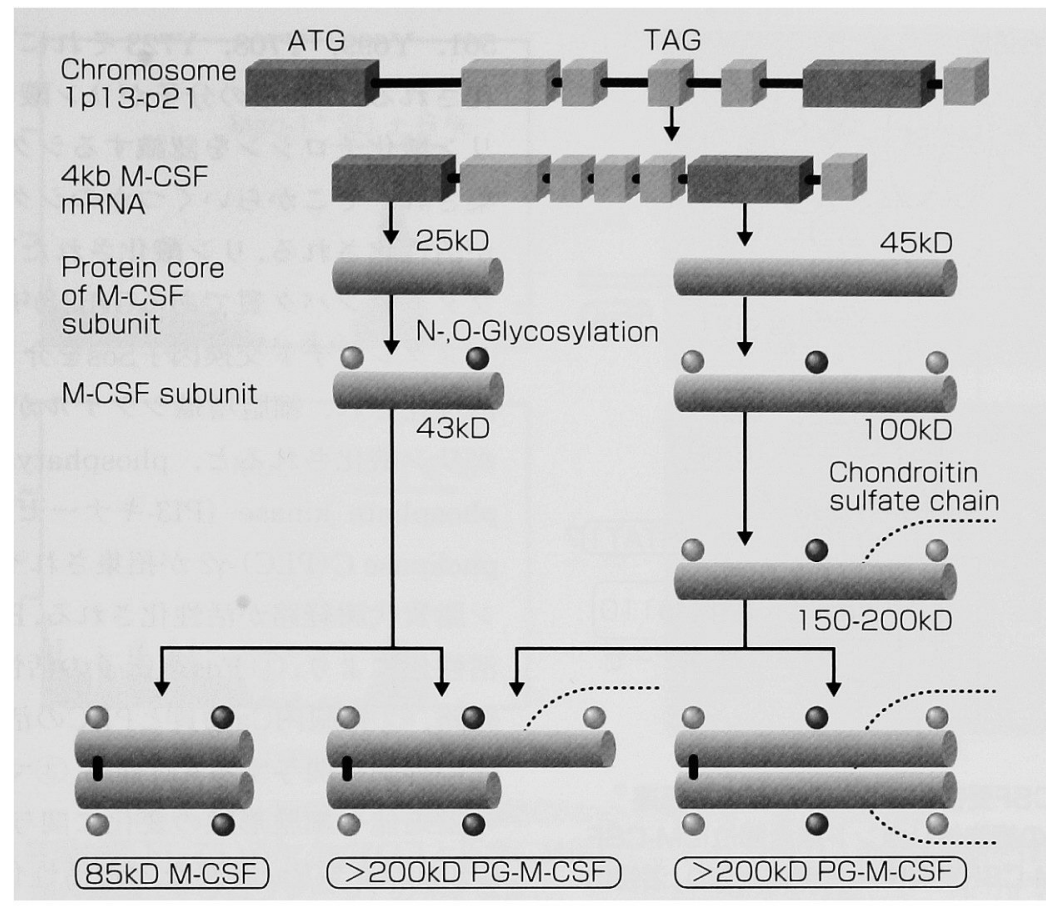

図 2. 3 種類のM-CSF分子が産生される過程

M-CSF遺伝子はヒトでは第 1 番染色体短腕 (1p13-p2 1) 上に 1 コピー存在し, それから 4kb mRNAが転写され, プロセッシングによって 25kDと 45kDの 2 本のプロテインコアができる. ついで0-あるいはN-糖鎖が結合して 43kDと 100kDサブユニットができ, 100kDサブユニッ トはさらにコンドロイチン硫酸鎖が 1 本結合して 150-200kDサブユニットとなる.それぞれの サブユニットはホモ 2 量体を形成するとともに, へテロ 2 量体も形成するので 3 種類のM-CSF 分子種ができる (文献 8 から引用).

USA)のGordon G. Wongらと共同でCSF-HUの 遺伝子クローニングに成功した5). CSF-HUの cDNA（p3ACSF-69）は 3,981 個のヌクレオチド からなり, 1 個のopen reading frameをもってお り,その 5 側にsignal peptide配列を持っていた. 遺伝子組換え型CSF-HUが大量に調製されin vitroおよびin vivoの実験が進むにつれて, CSFHUがM-CSFとよぶにふさわしいサイトカインで あることが判明したので, 筆者らは 1987 年第 16 回国際実験血液学会 (Tokyo) および国際モノカ インワークショップ (South Carolina, USA) に おいて，「CSF-HUをM-CSFと命名する」ことを 提唱して承認された。

M-CSF遺伝子はヒト第 1 番染色体 1p13-p21 に1コピー存在し, それから $4 \mathrm{~kb}$ mRNAがつく

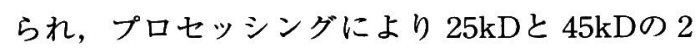
種類のタンパクコアが造られ，それぞれにNおよびO-糖鎖が結合して $43 \mathrm{kD}$ およ゙ $100 \mathrm{kD} の \mathrm{M}$ $\mathrm{CSF}$ サブユニットとなる. $100 \mathrm{kD}$ サブユニットは, さらに 1 本のコンドロイチン硫酸鎖が結合して 150-200kDサブユニットとなる.こうして造られ た 43kDサブユニットと 150-200kDサブユニット は, それぞれが 2 量体化してホモ 2 量体となる とともに, ヘテロ 2 量体も形成し, 合計 3 種類 の成熟型M-CSFが産生される (図 2).このうち 85kD-M-CSFは可溶型M-CSFであり血中に存在 するが, 2 種類のproteoglycan-type M-CSF (PGM-CSF) はコンドロイチン硫酸鎖を介して組織 の細胞外マトリックスのV型コラーゲンと結合し て存在する組織結合型M-CSFである ${ }^{9 \sim 11}$. 
細胞外りガンド結合領域

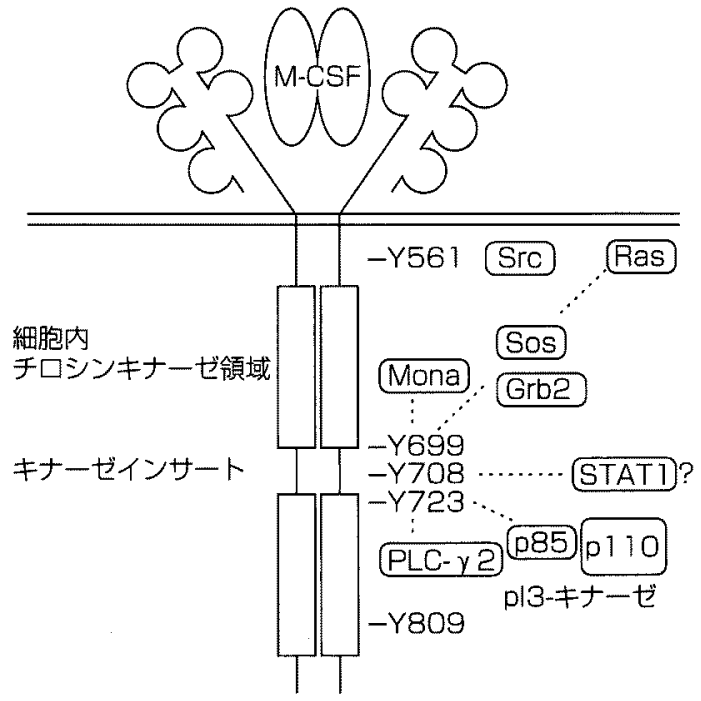

図 3. M-CSF受容体を介するシグナル伝達 M-CSF受容体の細胞外リガンド結合部位にM-CSF が結合するとM-CSF受容体は 2 量体となり，活性化 し, 細胞内のチロシン561(Y561),699(Y699), 708 (Y708), 723 (Y723), それに 809 (Y 809) がリン酸化される.リン酸化されたY699 にはGrb2 が召集され，Sosを経てRasに増殖シグナ ルが伝達される.またY723からはPI3-キナーゼや PLC-ソ2へとシグナルが伝達される.

M-CSFはCFU-Mから単球産生を刺激するととも に，単球の各種エフェクター機能（細菌や真菌 を貣食・殺菌する活性やサイトカイン産生能)を 刺激するサイトカインであった。

\section{M-CSF受容体を介するシグナル伝達}

M-CSF受容体（M-CSF-R）遺伝子は原癌遗伝 子c-fmsであり，ヒトでは第 5 染色体の長腕 (5q33.2-33.3)に位置し, その近傍にはGM-CSF, IL (interleukin)-3，IL-4，IL-5 の遺伝子がクラス ターを成している.M-CSFはM-CSF-Rと結合し て，それを 2 量体化することによって活性化す る(図 3)、M-CSFが 2 量体でないと生物活性を 持たないのはこのためである．活性化されたMCSF-Rは自己リン酸化によって分子内のtyr $(\mathrm{Y})$
561, Y699, Y708, Y723 それにY809 がリン酸 化される.これらの分子がリン酸化を受けると， リン酸化チロシンを認識するシグナル分子が招 集され，そこからいくつかのシグナル伝達経路 が活性化される、リン酸化されたY699にはアタ プタータンパク質であるGrb2 が結合し，グアニ ンヌクレオチド交換因子Sosを介してRas経路が 活性化され，細胞増殖シグナルが伝わる．Y723 がリン酸化されると, phosphatydyl-inositol 3phosphate kinase（PI3-キナーゼ）およびphospholipase C(PLC)- $\gamma 2$ が招集されイノシトールリ ン脂質代謝経路が活性化される.PI3-キナーゼの 活性化により,(1) Fos遺伝子の活性化一至るRas 経路, (2)細胞内Ca動員とPKCの活性化や, 細胞 死の抑制に関与するAkt経路, (3)マクロファージ の遊走能や細胞形態の変化に関与する低分子量 Gタンパク質Rac経路などが活性化される。筆者 らはCbがPI3-キナーゼのp85 サブユニットと会 合することで, これらの経路に関与しているこ とを見出している12).

最近, 筆者らはマクロファージをM-CSFやGMCSFやIL-3 で刺激するとドッキング蛋白 $\mathrm{p} 56^{\mathrm{DOK} 2}$ の発現が誘導されること，および骨髄性白血病 細胞にp56 $6^{\mathrm{DOK} 2}$ 強制発現すると，その細胞の M-CSF, GM-CSF, IL-3, SCF存在下での增殖が 強く抑制されることを発見した ${ }^{13.14)}$. 事実,この 分子の発現が低下している $\mathrm{hr} / \mathrm{hr}$ マウスでは, 腹 腔マクロファージの数が明らかに増加していた (図 4).

\section{M-CSFの生物活性}

M-CSFはマクロファージコロニー刺激因子と して発見されたが, 研究を進めるにつれて極め て広範な生物活性をもった多機能性因子である ことが明らかとなった:

\section{1）破骨細胞增殖分化作用}

全身骨の硬化，䯣外造血，単球減少などを特 徴とする大理石病のモデル動物であるop/opマウ 


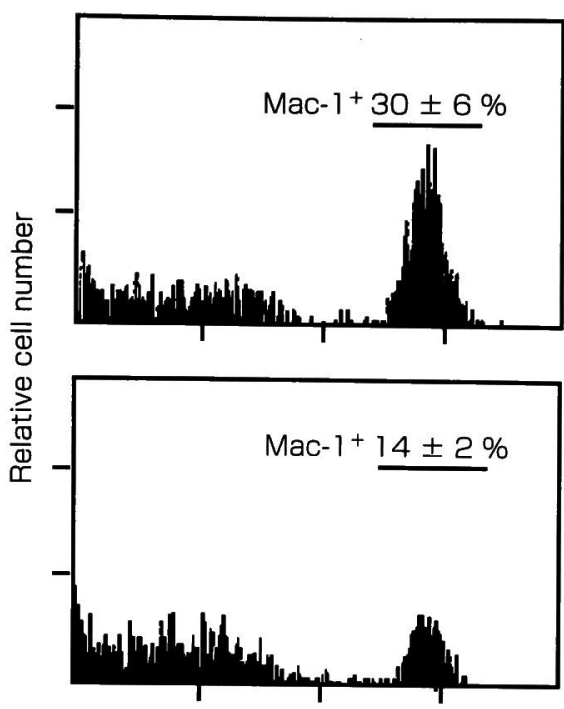

Log fluorescence intensity

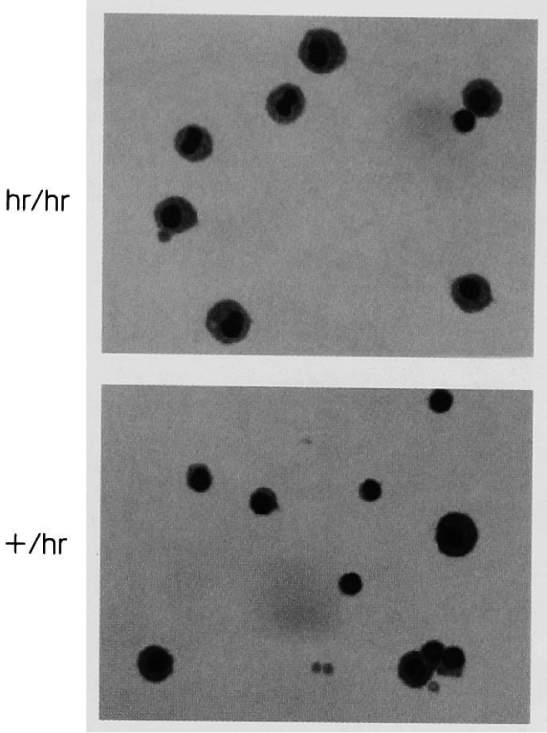

図 4. $\mathrm{Hr} / \mathrm{hr}$ マウスの腹腔細胞のMac- 1 発現率と塗沫染色標本

Doc 2 発現が低下しているhr/hrマウスと正常に発現している+/hrマウスの腹腔細胞を採取して, Mac-1 陽性細胞 (マクロファージ) の\%を測定し，さらに塗沫標本を作成した. Hr/hrマウスで は+/hr (正常) マウスに比べて, Mac-1 陽性細胞の\%が上昇し, 形態的にマクロファージと同 定できる細胞数が明らかに増加していた. このことからDoc2 がマクロファージ増殖を抑制する 分子であることがわかった (文献 13 から引用).

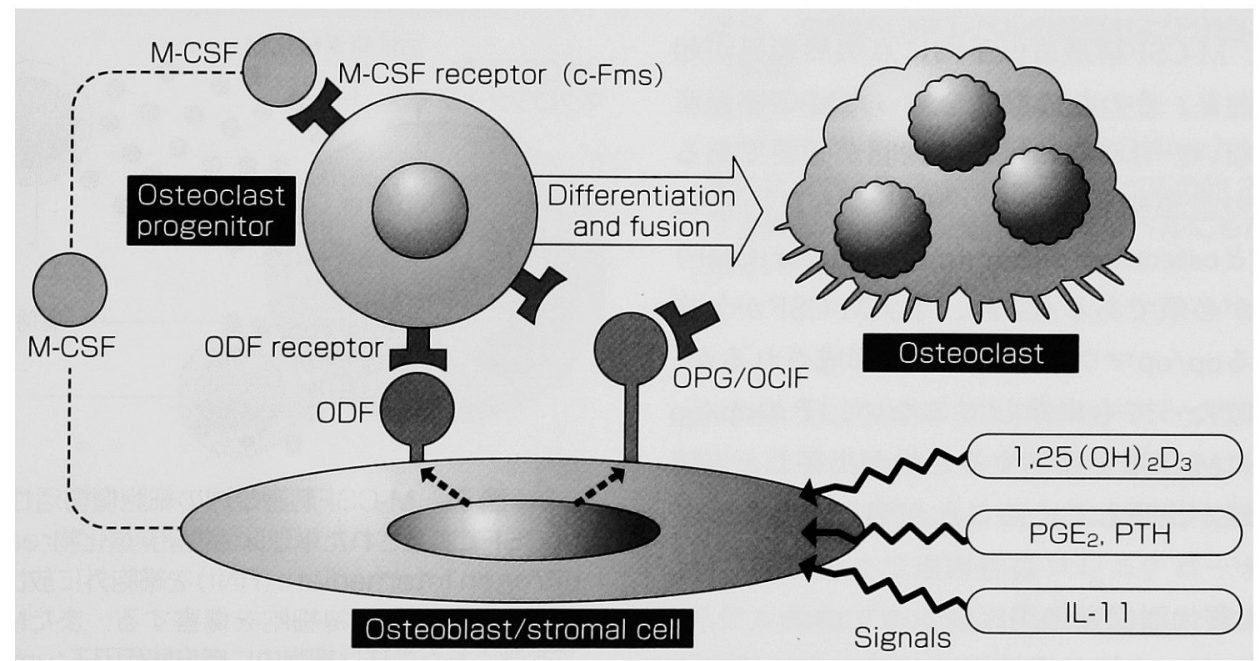

図 5. 破骨細胞の分化

破骨細胞前駆細胞（osteoclast progenitor）はM-CSF受容体とODF (osteoclast differentiation factor) 受容体を発現しており，骨芽細胞や間質細胞が産生するM-CSFとODFの刺激に より破骨細胞(osteoclast)へと分化する.骨吸収シグナルである 1,25(OH) 2D 3 , PGE2, PTH, IL-1 1 は骨芽細胞や間質細胞のM-CSFやODF産生を刺激することによって破骨細胞の産生を六進 する. 


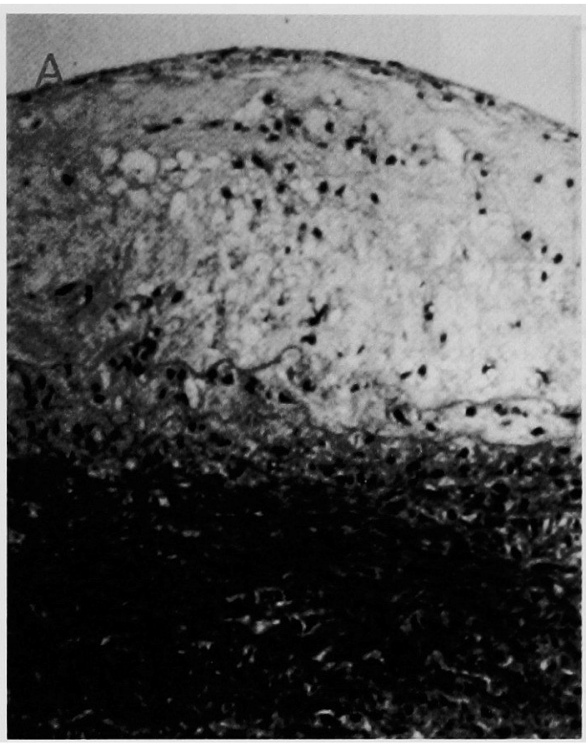

Saline injection

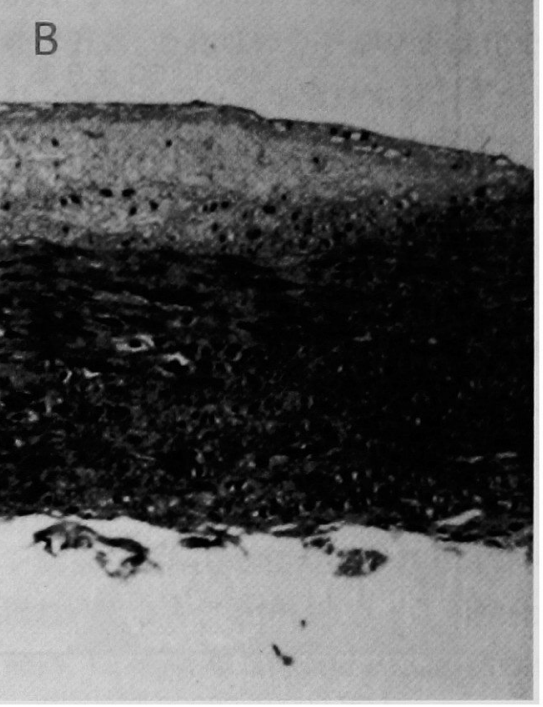

M-CSF injection

図 6. 渡辺遗伝性高脂血症ウサギの動脈切片

渡辺遺伝性高脂血症 (Watanabe heritable hyperlipidemic=WHHL) ウサギにM-CSFまたは 生理食塩水を 8 力月間投与したのち, 大動脈の切片を作製した. 生理食塩水投与を受けたウサギ の動眽では動眽硬化が進展していたが, M-CSF投与を受けたウサギの動眽では明らかに動眽硬化 の進展が遅かった（文献 16 から引用）。

スでは, M-CSF構造遺伝子内に点突然変異が起 こっており，そのため機能をもったM-CSFが産 生されない。骨吸収には破骨細胞が必要である が，その前駆細胞が分化・成熟するためには M-CSF と osteoclast differentiation factor (ODF) の両方が必須である (図 5). 事実M-CSFが欠損 しているop/opマウスでは歯芽は形成されるが, いつまでたっても出芽してこない，そのop/op マウスにM-CSFを投与すると歯が出芽し, 末梢 血に単球が出現してくることが明らかとなって いる.

\section{2）脂質代謝促進作用}

筆者らが，小児の慢性好中球減少症に対する M-CSFの投与効果を調べる臨床試験を実施して いたとき，M-CSF投与を受けた患者全員におい て，血清総コレステロール值が-9.5〜 - 33.9\% も減少していることに気づいた ${ }^{15)}$. それ以後, M-CSFの脂質代謝におよぼす影響についてin vi-

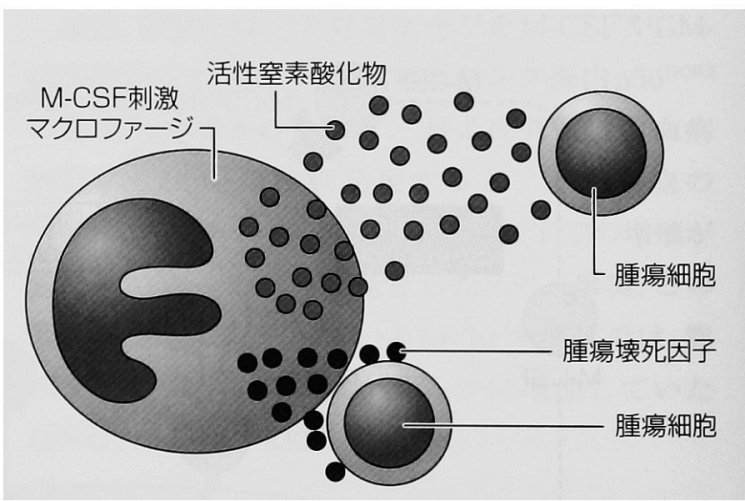

図 7.M-CSF刺激単球の細胞傷害活性 M-CSFで刺激された単球は活性㗝素酸化物reactive nitrogen internediate(RNI)を細胞外に放出して, 単球から離れた腫瘍細胞を傷害する. またM-CSF で刺激された単球は細胞内に腫場壊死因子tumor necrosis factor (TNF) をため込んでおり (プライミ ング)、腫瘍細胞が単球に接触する(トリガリング) とTNFを局所的に分泌してその睡場細胞を傷害する. 


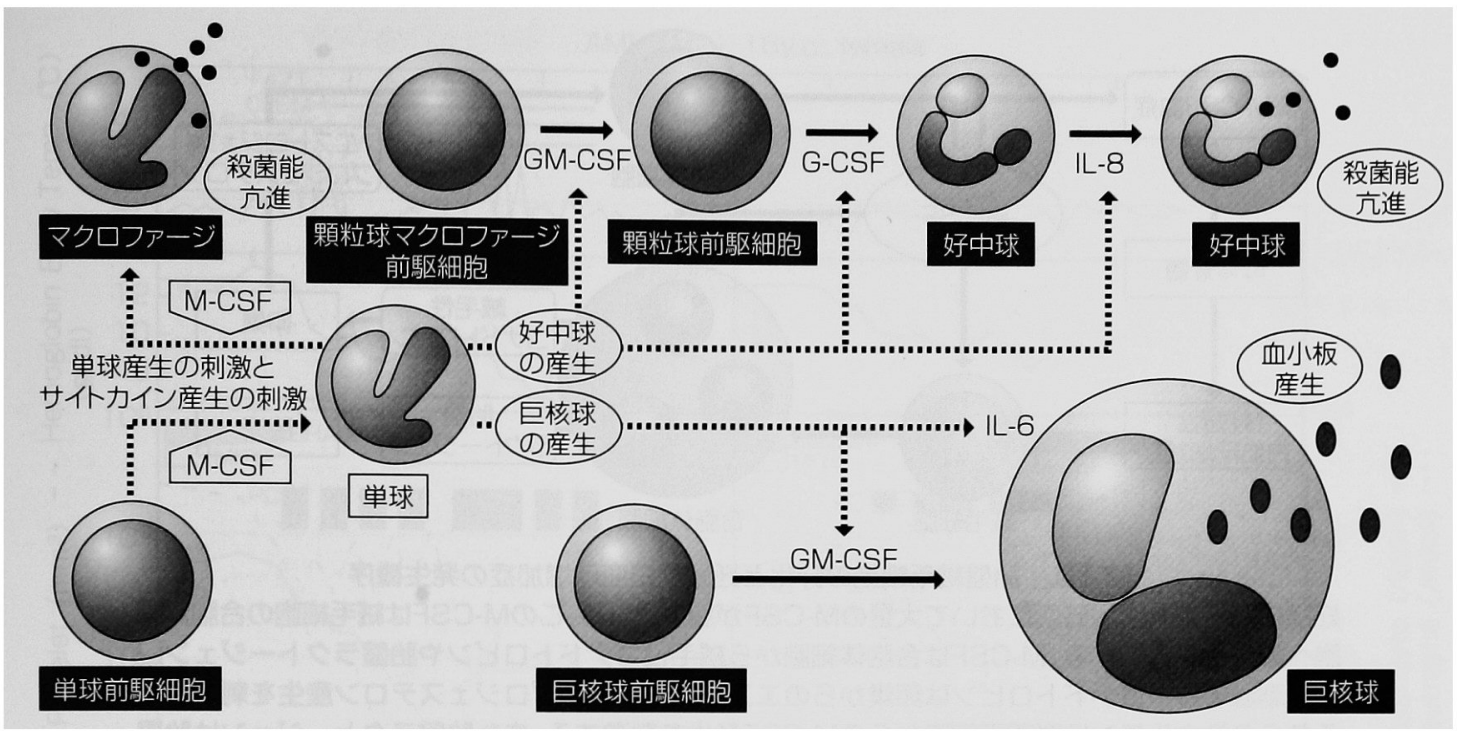

図 8. 造血のサイトカインネットワーク機構

M-CSFは単球/マクロファージ産生を刺激するとともに，成熟単球/マクロファージの各種機能, すなわち殺菌能やサイトカイン(GM-CSF， G-CSF，IL-6，それにIL-8)産生能を刺激する.GMCSFとG-CSFは好中球産生を刺激し，IL-8 は好中球の殺菌能を刺激する. またGM-CSFは巨核 球の産生を刺激し，IL-6 は血小板産生を刺激する．このように骨夠における各種血球産生はMCSFを中心としたサイトカインネットワークによって調節されている（文献８から引用）.

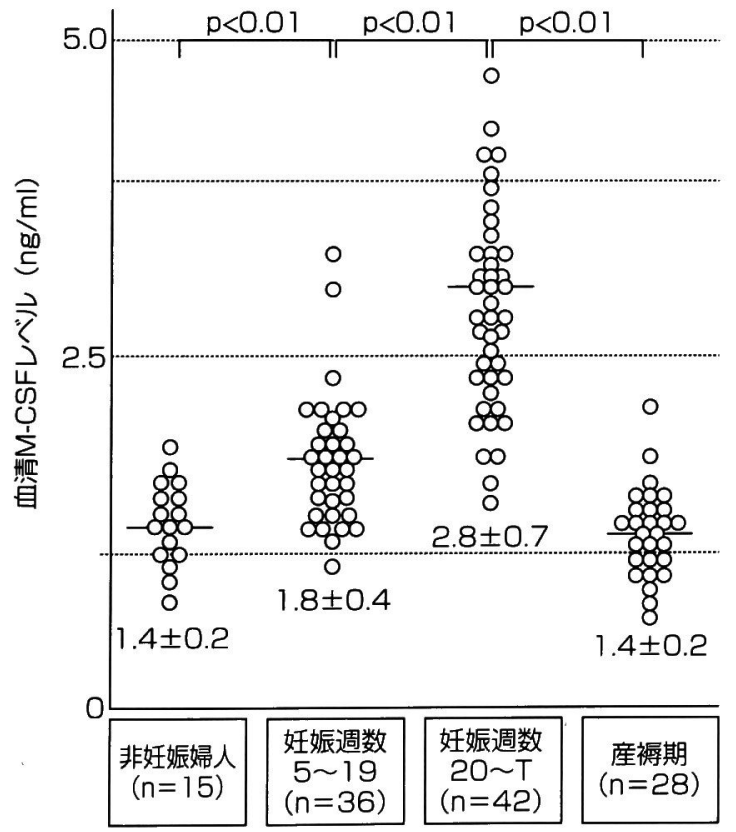

troおよびin vivoでの研究が進展した. その結果, M-CSFは低比重りポタンパクlow-density lipo-

\begin{abstract}
図 9. 血清M-CSFレベルの妊娠および分娩にともな う変動

血清M-CSFレベルは非妊娠婦人では 1.4 $00.2 n g /$ $\mathrm{ml}$ でるが, 妊娠前期には $1.8 \pm 0.4 \mathrm{ng} / \mathrm{ml}$, 妊娠後 期には 2.8 $\pm 0.7 \mathrm{ng} / \mathrm{ml}$ 正常レベルの約 2 倍にま で上昇し, 分婏後 2 週間で正常レベルにもどる（文 献 23 から引用).
\end{abstract}

protein（LDL）のマクロファージへの取り込み も，またマクロファージ内のコレステロールプー ルからの取り出しも，ともに刺激することがわ かった. そこで家族性高コレステロール血症の モデル動物である渡辺遺伝性高コレステロール 血症ウサギ（渡辺ウサギ）に，8 カ月間M-CSF あるいは生理食塩水を投与して動脈硬化進展の 程度を比較したところ，M-CSF投与によって動 脈硬化進展が明らかに阻止されていることが証 明された（図 6) ${ }^{16)}$. 


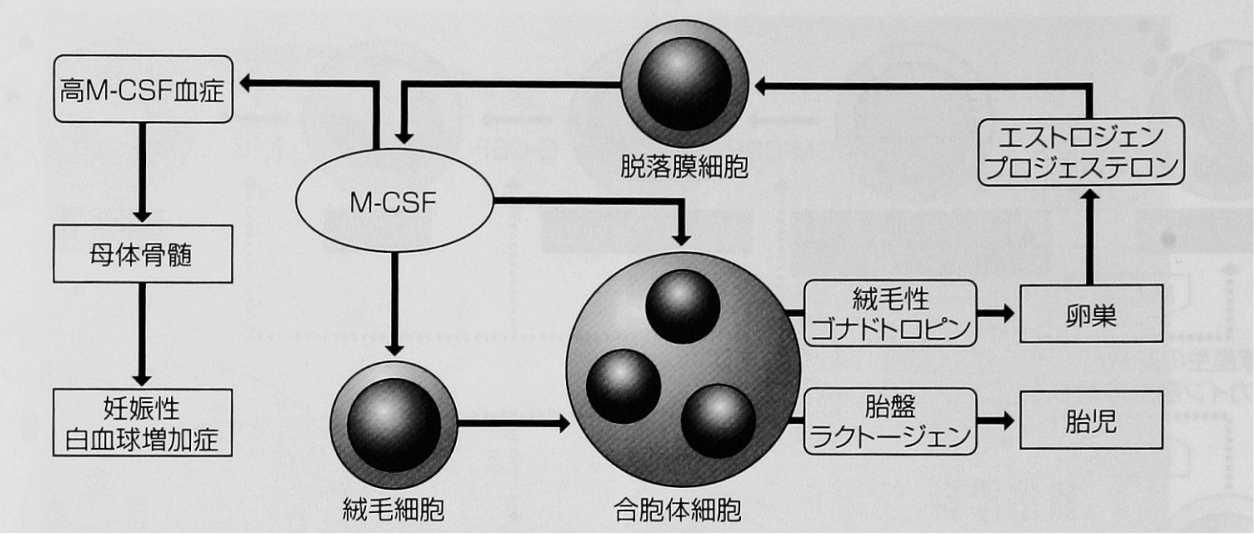

図 10. 胎盤絨毛細胞の分化と妊娠性白血球増加症の発生機序

妊娠に際して胎盤脱落膜において大量のM-CSFが産生される.このM-CSFは䄉毛細胞の合胞体細 胞への分化を促進する.M-CSFは合胞体細胞から緁毛性ゴナドトロピンや胎盤ラクトージェン産 生を刺激する.ゴナドトロピンは卵巣からのエストロジェンやプロジェステロン産生を刺激し， それらの性ホルモンは脱落膜細胞からのM-CSF産生を刺激する. また胎盤ラクトージェンは胎児 の発育に必須の物質である. 一方, 胎盤局所で産生される大量のM-CSFは母体血中に逸脱し，母 体は高M-CSF血症となり，M-CSFが母体骨檤での白血球造血を刺激するので娃娠性白血球増加症 となる.

\section{3）細胞傷害活性}

M-CSFは単球のFc受容体発現を増強すること によってantibody-dependent cell-mediated cytotoxcitity (ADCC)を増強する.またM-CSFは単 球の腫瘍壊死因子tumor necrosis factor (TNF) や活性窒素酸化物 reactive nitrogen intermediate（RNI）の産生を増幅することによって，単 球の細胞傷害活性を増強する (図 7) ${ }^{17,18)}$.

4）M-CSFの造血刺激作用

筆者らはヒト単球をM-CSFで刺激した場合, どんなサイトカインが培養上清中に産生される かをin vitroで解析した ${ }^{19)}$. その結果ヒト単球は M-CSFで刺激されなくても少量の顆粒球コロ 二ー刺激因子granulocyte colony-stimulating factor (G-CSF) pinterleukin 6 (IL-6) やIL-8 を産生しているが，M-CSFで刺激された単球は 大量のG-CSF, IL-6, IL-8 を産生するとともに, 大量のgranulocyte-macrophage CSF (GM-CSF) も産生することがわかった. 産生されたGM-CSF はCFU-GMからCFU-GとCFU-Mを産生し,CFU-G はG-CSFによって好中球へと分化し, CFU-M
EFFECT OF hM-CSF ON SURVIVAL RATE AFTER BMT

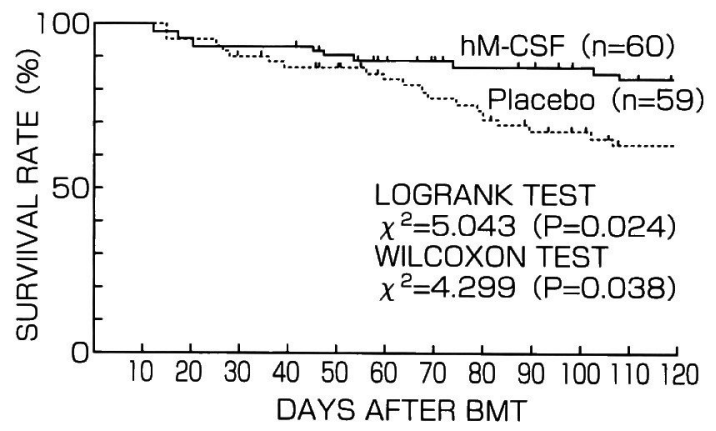

図 11.M-CSF/BMT試験における第 120 日目ま での生着生存率

骨髄移植を受けた患者を 2 群に分け, hM-CSF群に はM-CSF 800 万単位を, placebo群にはplacebo を、それぞれ 14 日間投与した. 移植後 120 日まで の生着生存 (再移植なしで生存) 率はhM-CSF群の 方が統計的有意にプラセボ群より高かった（文献 25 から引用).

はM-CSF自身によって単球へと分化する。一方 IL-8 は好中球の細菌に対する貪食・殺菌能を元 進する ${ }^{20)}$.またGM-CSFはCFU-GMから巨核球 


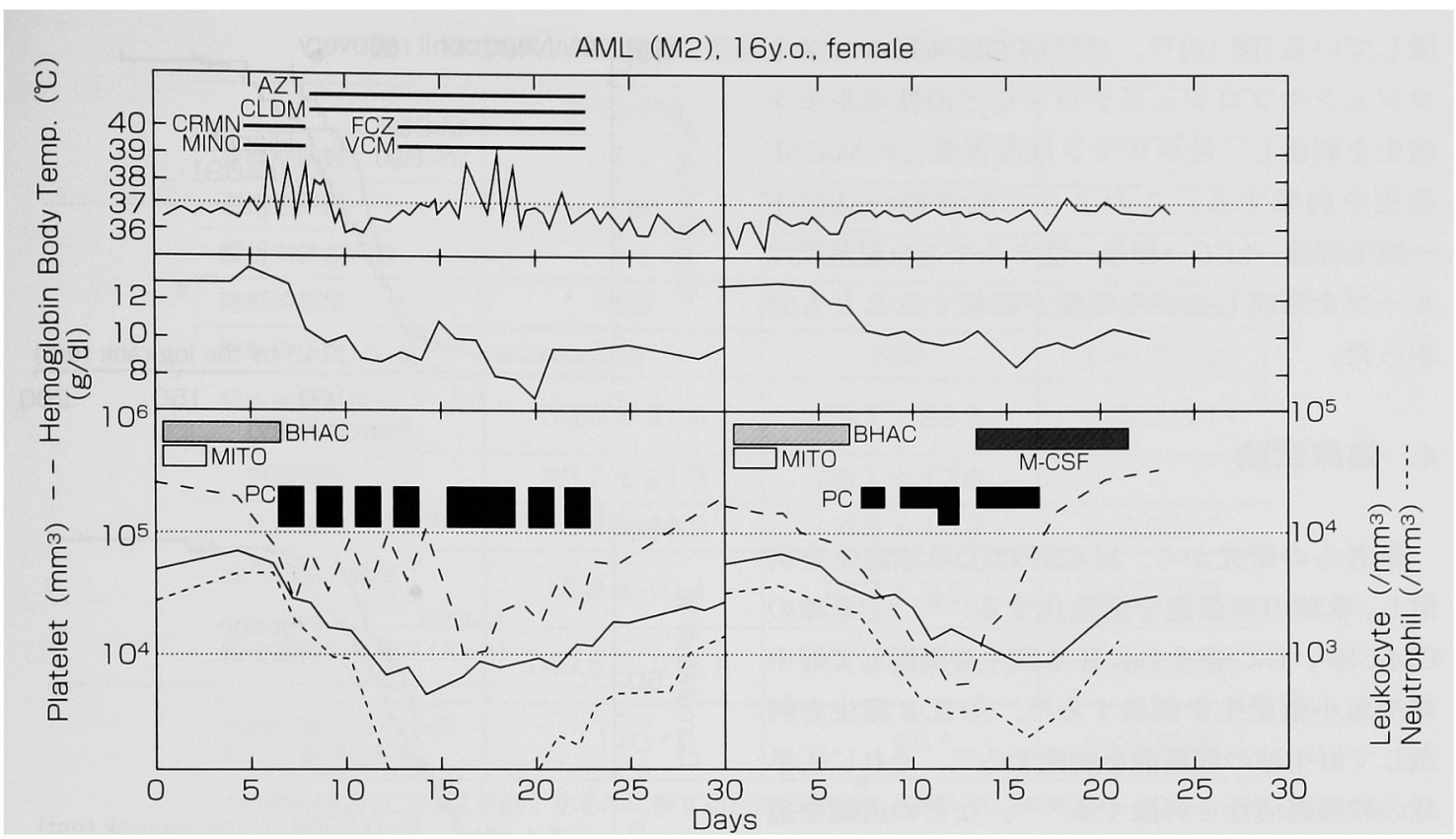

図 12.M-CSF投与が有効であったAML症例

急性骨髄性白血病 (AML) でFAB分類M2 の 16 歳の女性が完全寛解到達後，同一メニューの化 学療法 (BHAC+MITO) を 2 回受けた. 1 回目はM-CSFを使用せず， 2 回目にM-CSFを使用 した. 白血球数，好中球数，それに血小板数の回復はM-CSFを使用した2 回目において明らかに 早かった. また 1 回目の化学療法後は感染症を合併し, 大量の静注用抗生物質を使用し, また大 量の血小板輸血が必要であったが，2 回目の化学療法後は感染症を合併せず，また血小板輸血量 も半分以下ですんだ.

の産生を刺激し, IL-6 は巨核球から血小板の産 生を刺激する．従ってM-CSFは単球と好中球と 血小板の産生を立進するとともに，単球や好中 球の細菌や真菌を䕘食・殺菌する活性を立進す ることがわかった (図 8). 最近筆者らはM-CSF がNK（natural killer）細胞增殖促進活性をもっ ていることを明らかとした ${ }^{21.22) .}$

\section{5）妊娠性白血球增加症}

妊娠婦人は感染症が無くても白血球増加症と なることが以前から知られていたが, 筆者らの 研究から，その原因がM-CSFであることが明か となった．すなわち妊娠に際して胎盤脱落膜で 大量のM-CSFが産生されており，それが母体血 中に逸脱して，母体が高M-CSF血症となり ${ }^{23)}$, それが骨䯣で白血球を増産させるために白血球 増加症となるのである。この妊娠性白血球増加
症は単球増加症と好中球増加症からなり, 高 M-CSF血症によって単球だけでなく好中球も産 生されることを示している（図 9）.

\section{6）䄉毛細胞分化誘導作用}

筆者らは妊娠性白血球増加症の発症メカニズ ムを解明する研究から, 妊娠にさいしては胎盤 局所において極めて大量のM-CSFが産生されて いることを明らかとした。 ついで妊娠にさいし て何故M-CSFが必要なのかについて研究を進め た結果, M-CSFが未熟な単核の䄉毛細胞 (cytotrophoblast) が細胞融合を繰り返しながら多核の 成熟した合胞体細胞 (syncytiotrophoblast)へと 分化する過程に必須の因子であることを発見し た. 成熟した合胞体細胞はhuman chorionic gonadotropin ( $\mathrm{hCG}$ ) やhuman placental lactogen （hPL）を分泌して，胎盤維持や胎児の発育を刺 
激している(図 10) ${ }^{24)}$ 。またhCGは卵巣のエスト ロジェンやプロジェステロンなどの性ホルモン 産生を刺激し，性ホルモンは脱落膜でのM-CSF 産生を刺激する。このように脱落膜 $\rightarrow \mathrm{M}-\mathrm{CSF}$ $\rightarrow$ 䄉毛緢胞 $\rightarrow \mathrm{hCG} \rightarrow$ 卵巣 $\rightarrow$ 性ホルモン $\rightarrow$ 脱落膜は ループを形成しながら妊娠が継続することも分 かった。

\section{4. 臨床試験}

筆者らの研究から, M-CSFは(1)単球産生を刺 激し, 単球の殺菌能を活性化する ${ }^{1 \sim 3)}$, (2)単球の GM-CSF，G-CSFそれにIL-6 産生を刺激して好中 球や血小板産生を刺激する ${ }^{19)}$ ，(3) IL-8 産生を刺 激して好中球の殺菌能を刺激する ${ }^{20)}$ ，それに(4)単 球の殺腫演活性を刺激する ${ }^{17,18)}$ ，などの広範な造 血刺激活性を持っていることが明らかとなった。 そこで筆者らはM-CSFの造血刺激効果, 感染症 防止効果, 再発防止効果などを臨床的に実証す るための大規模二重盲検比較試験を骨髄移植bone marrow transplantation (BMT) 患者 (M-CSFBMT試験)，急性骨䯣性白血病acute myeloid leukemia (AML) 患者（M-CSF-AML試験），およ び卵巣癌ovarian cancer（OVA）患者（M-CSFOVA試験）において実施した。

\section{1) M-CSF-BMT試験}

急性白血病，慢性白血病それに再生不良性㙰 血患者に対する同種骨髄移植allogeneic BMT (allo-BMT)はこれらの疾患の根治療法であるが, (1)移植後の感染 (infection), 出血 (bleeding), 生着不全 (graft failure), (2)移植片対宿主病 graftversus-host disease (GVHD)，それに(3)原病の 再発，などの臨床的課題を残している．筆者ら はM-CSF投与効果を評価するための 2 重盲検比 較試験を 1986 年から 1987 年にかけて全国 34 施設の参加を得て実施した ${ }^{25 !}$ 。この臨休試験にお いて 119 名のBMT症例が登録され，無作為に実 薬 (M-CSF) 群とプラセボ (placebo) 群に分け られた。その結果, M-CSF群ではplacebo群に比
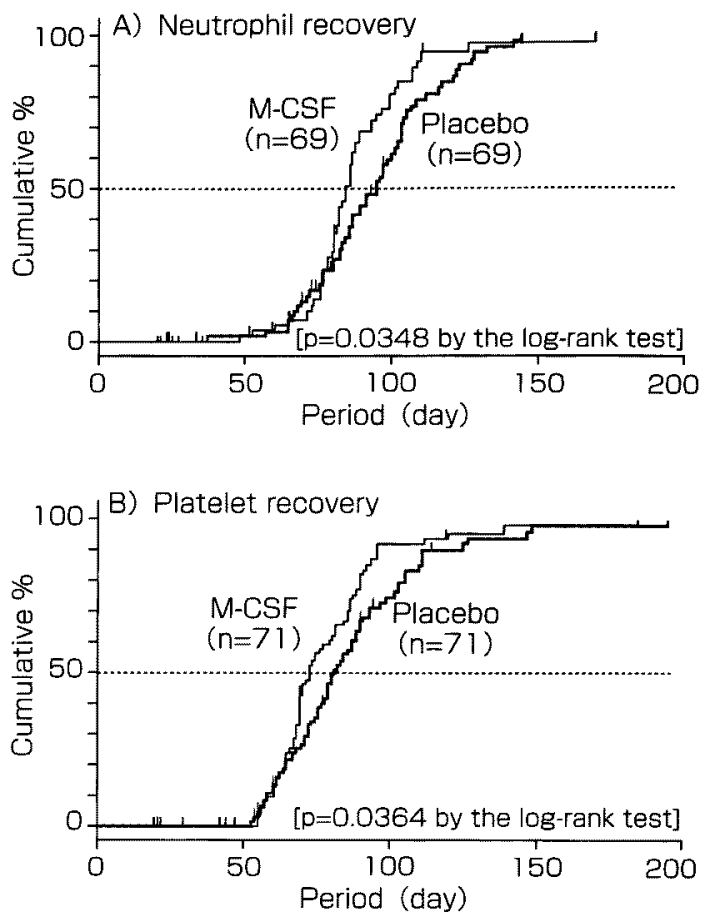

図 13. 化学療法後の好中球と血小板の回復におよ ぼすM-CSFの投与効果（M-CSF-AML試験） M-CSF投与群の好中球数 (A) および血小板数 (B) の回復はplacebo投与群のそれらに比較して, 統計 的有意に早かった．横軸は地固め療法ごとに好中球 数>1,000 (A)，あるいは血小板数>100,000

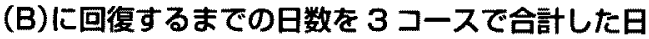
数を示し，綎軸は累積\%を示す.M-CSF投与が化学 療法後の好中球や血小板の回復を促進することが証 明された（文献 26 から引用)。

ベて統計的有意 $(\mathrm{p}=0.011)$ に好中球回復が早い ことが示された。さらにBMT後 120 日目までの 生着生存率 (BMT後生着不全をおこさず生存し ている患者の\%) はM-CSF群 50/60（83\%）に対 してplacebo群 39/59（66\%）であり統計的有意 $(\mathrm{p}=0.024)$ にM-CSF群で高いことが示された (図 11).

最近この臨床試験に登録された患者の長期予 後調査が実施され，慢性骨髄性白血病chronic myeloid leukemia (CML) 患者では, M-CSF群 $(\mathrm{n}=15)$ で 73.3\%に対してplacebo群 $(\mathrm{n}=8)$ で 
表、M-CSF/AML 試験で証明された M-CSF の臨床効果

\begin{tabular}{|c|c|c|c|}
\hline & プラセボ群 & M-CSF 群 & \\
\hline 登録症例数 & 101 & 97 & \\
\hline 適格症例数 & 94 & 90 & \\
\hline 解析対象症例数 & 94 & 88 & \\
\hline 総感染頻度 & 185 & 133 & $p=0.0206$ \\
\hline 総感染日数 & 977 & 565 & $p=0.0029$ \\
\hline $\begin{array}{l}\text { 抗生物質静脈内 } \\
\text { 投与日数 (日) }\end{array}$ & $39.5 \pm 31.6$ & $29.7 \pm 22.9$ & $p=0.0171$ \\
\hline 抗細菌㨈（日） & $29.7 \pm 21.3$ & $25.1 \pm 17.6$ & \\
\hline 抗真菌珮（日） & $9.8 \pm 16.3$ & $4.6 \pm 10.2$ & $p=0.0097$ \\
\hline $\begin{array}{r}\text { 血小板輸血頻度 } \\
\text { (日) }\end{array}$ & $12.8 \pm 10.4$ & $10.7 \pm 9.6$ & $p=0.0259$ \\
\hline $\begin{array}{r}\text { 血小板輸血総量 } \\
\text { (单位) }\end{array}$ & $149.5 \pm 162.1$ & $114.6 \pm 102.1$ & $p=0.0292$ \\
\hline $\begin{array}{l}\text { 地固め療法 } 3 コ 一 ス ~ \\
\text { 終了に要する数 }\end{array}$ & $110^{*}$ & $93^{*}$ & $p=0.0050$ \\
\hline
\end{tabular}

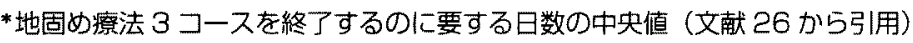

は $25 \%$ であり，統計的有意（ $\mathrm{p}=0.016 ） に \mathrm{M}$ CSF群で長期生存率が高かった。

\section{2) M-CSF-AML試験}

筆者らは臨床第 2 相試験に招いて，M-CSF 投与が多剂併用化学療法を受けたAML患者の好 中球や血小板の回復を促進することをしばしば 経験した (図 12)。そこで 1992 年から 1995 年に かけてJALSG (Japan Adult Leukemia Study Group）と共同でM-CSFの臨床効果を評価するた め大規模 2 重盲検比較試験を実施した (M-CSFAML 試験 $)^{26)}$ 。この臨床試験には全国 42 施設が 参加した. JALSG-AML92 プロトコールで完全 寛解に到達し, 3 回の地固め療法を受ける直前の AML患者 198 人が登録され，無作為にプラセボ (placebo) 群（化療翌日からプラセボを 14 日間 投与）とM-CSF群（化療翌日からM-CSF 800 万 単位/日を 14 日間投与)に振り分けられた。placebo群の 94 例とM-CSF群の 88 例が評価可能で あった。

好中球数回復はM-CSF群のほうがplacebo群よ り明かに早く $(P=0.0348$ ) (図 13A)，また感染症
の総頻度と総期間はM-CSF群では 133 回と 565 日であるのに, placebo群では 185 回と 977 日で あり，M-CSF群で大幅に減少していた（p= $0.0206, \mathrm{p}=0.0029$ ) (表). 起炎菌の検出頻度を比 較するとPlacebo群 73 回に対してM-CSF群 48 回と大幅に減少しており，M-CSFの強い感染防 御効果を示していた。グラム陽性菌も陰性菌も 大幅に減少していたが，特にMRSA（methicillin resistant S. aureus) と真菌の検出頻度が激減 しており，M-CSFのそれらの菌に対する強い防 御効果を示していた。抗真菌薬の静脈内投与日 数もM-CSF群ではplacebo群に比べて $1 / 2$ 以下で あった。

血小板数回復もM-CSF群で明らかに早く( $\mathrm{p}=$ 0.0364)（図 13B），血小板輸血頻度と血小板輸血 量はM-CSF群では 10.7 日と 114.6 単位であり， placebo群の 12.8 日と 149.5 単位に比べて統計的 有意（ $p=0.0259, p=0.0292 ） に$ 改善していた. 最近, Hatakeらはこの臨床試験に登録された患 者の地固め療法開始から 8 年後の長期予後調查 を実施し，65 歳以下でFAB分類M4 以外の患者 

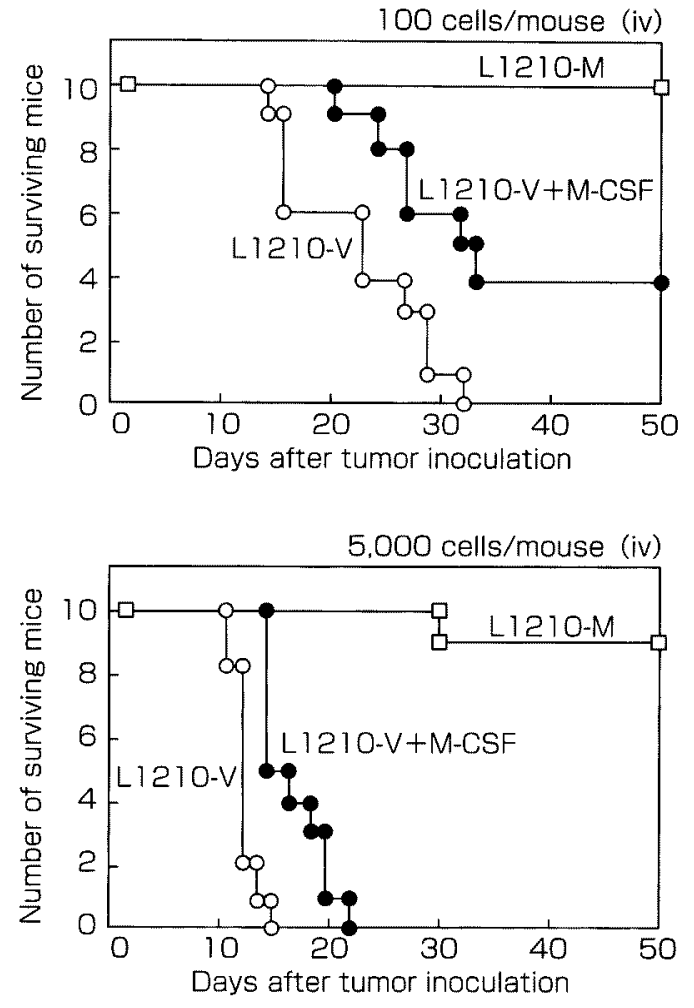

図 14. M-CSF㯰伝子導入L1210 細胞の静脈内接 種後の生存率

リンパ性白血病株細胞 (L1210)に遗伝子導入用ベ クターだけを導入したL 1210-VとM-CSF遗伝子を

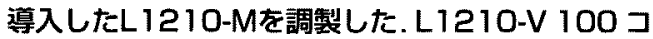
を接種して経過を観察する群 (L1210-V群), L1210-V 100 コを接種してM-CSFで治療する群 (L1210-V+M-CSF群)，それにL-1210-M 100 コを接種して経過を観察する群（L1210-M群）の 3群に分けた(上のパネル). 下のパネルは同様の実 験を 5,000 コ接種して行った. この研究から，(1) L1210-Vを静眽内接種すると致死的であること,(2) L1210-Vが少ない場合はM-CSF投与がある程度有 効であること，それに(3) L1210-Mのように腫瘍細 胞自身がM-CSFを産生する場合は腫瘍免疫が強く誘 導されて、ほとんどのマウスが生存することがわかっ た (文献 28 から引用) 。

ではM-CSF投与が統計的有意に生存率を高めて いることを明らかとした（Hatake K: personal communication, 2003).

日本内科学会雑誌 第93巻 莪 9 号・平成16年 9 月10日

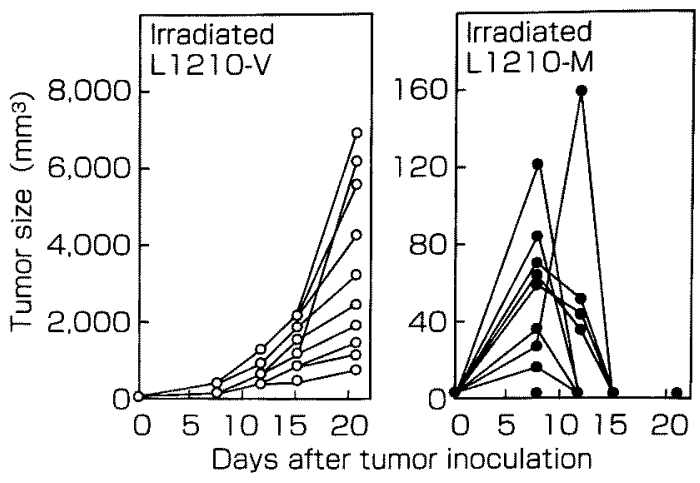

図 15. 放射線照射L 1210-M細胞の皮下按種により 腫煬免疫が誘導される

L1210-VとL1210-Mを放射線照射してからマウス の背部皮下に接種して,その後し 1210 親株細胞を反 対側の皮下に接種して，その後の腫癗の増大を測定 した.あらかじめ放射線照射L1210-Vを皮下接種し ておいたマウスでは親株細胞は増殖を続け皮下腫痬 は増大する一方であったが，あらかじめ放射線照射 L1210-Mを皮下接種しておいたマウスでは一旦小さ な皮下腫瘤ができたが，その後自然に消退した。こ のことはM-CSF遺伝子導入腫歾細胞を放射線照射し てから皮下接種することによって睡瘍免疫が誘導さ れることを示している.

\section{3) M-CSF-OVA試験}

M-CSF-OVA2 重盲検比較試験は 1992 年から 1996 年にかけて全国 63 施設が参加して実施され $た^{27}$. CAP療法 (cyclophosphamide, adriamycin, cisplatin）を3クール以上予定したI〜II 期卵巣癌患者で，第 1 クールの化学療法で好中 球が 1,000 以下となった患者を無作為に 2 群に分 け，1群にはM-CSF 800 万単位/日（M-CSF群） を，また他の群にはM-CSF 100 万単位/日(この 量は無作用量) (control群)を 7 日間投与した. 発熱性好中球減少症日数扔上び非発熱性好中球 減少症日数はM-CSF群で 13 日および 5,823 日で あり, control群 27 日および 6,218 日に比べて統 計的有意 $(\mathrm{p}=0.040)$ に-CSF群で発熱性好中球 減少症日数の短縮が認められた。この試験に登 録された患者のうち最初の手術で残存腫煬が無 かった症例の再発率はM-CSF群の方がcontrol 群より統計的有意に低かった。 


\section{M-CSF遺伝子を用いた免疫遺伝子治療}

M-CSF遺伝子を腫湯細胞に導入してマウスに 接種することによってその腫瘍に対する腫瘍免 疫を誘導することができることが証明され た ${ }^{28 \sim 30)}$. L1210 リンパ性白血病株細胞に遺伝子導 入vectorのみを導入したL1210-Vと,M-CSF遺伝 子を導入したL1210-Mを調製した.L1210-Vを 100 コ/マウス, 尾静脈から接種すると 32 日で全て 死亡したが, M-CSFで 3 日間治療 (L1210-V + MCSF）すると 40\%のマウスが長期間生存した (図 14).一方L1210-Mを 100 コ/マウス接種して も 100\%のマウスが長期間生存した. L1210-V を 5,000 コ/マウス静脈内接種すると 14 日間で全 て死亡し, M-CSFで治療 (L1210-V + M-CSF) し ても 22 日間ですべてのマウスが死亡した.一方 L1210-Mを 5,000 コ/マウス接種しても 90\%のマ ウスが長期生存し,生き残ったL1210-MにL1210 親株細胞を再接種しても全てのマウスが生存し た.

マウス背面の皮下に放射線照射L1210-V と放射 線照射L1210-Mを接種しておいてから，L1210 親株細胞を反対側の皮下に接種して，皮下腫瘤 の増大を経時的に測定した。あらかじめ放射線 照射L1210-Vを接種しておいたマウスでは腫瘤は 増大する一方であったが，あらかじめ放射線照 射L1210-Mを接種しておいたマウスでは小さな腫 馏ができたが,その後自然に消退していった(図 15).このことは腫瘍細胞にM-CSF遺伝子を導入 し，放射線照射してから皮下接種することによっ て腫瘍免疫を誘導することができることを示し ている.

このM-CSF遺伝子を用いた急性白血病の免疫 遺伝子治療は将来急性白血病の再発防止法とし て臨床応用されることが期待されている.
おわりに

筆者らの研究から造血のサイトカインによる 分子調節機構が明らかとなった8). 今後は(1)造血 機構を細胞内シグナル伝達分子や転写因子のレ ベルで解析すること，(2)白血病細胞やリンパ腫 細胞におけるシグナル伝達や転写の異常を解析 すること，それに(3)異常なシグナル分子や転写 因子を標的とした分子標的治療薬の開発，など が重要な研究課題となろう。

\section{文献}

1) Motoyoshi K, et al: Purification and some properties of colony-stimulating factor from human urine. Blood 52 : 1012-1020, 1978.

2) Motoyoshi K, et al: Granulocyte-macrophage colonystimulating and binding activities of purified human urinary colony-stimulating factor to murine and human bone marrow cells. Blood 60 : 1378-1386, 1982.

3) Motoyoshi $\mathrm{K}$, et al: High serum colony-stimulating activity of leukocytopenic patients after intravenous infusions of human urinary colony-stimulating factor. Blood $62: 685-688,1983$.

4) Hatake $\mathrm{K}$, et al : Purification of human urinary colonystimulating factor by high performance liquid chromatography. J Chromato 344 : 339-344, 1985.

5) Wong G, et al : Molecular cloning and expression of $4 \mathrm{~kb}$ cDNA encoding the human urinary protein Science 235 : 1504-1508. 1987.

6) Motoyoshi $K$, et al:Regulatory mechanism of granulopoiesis in the bone marrow of CSF-producing tumorbearing nude mice. Blood $62: 980-987,1983$.

7) Motoyoshi $\mathrm{K}$, et al : Inhibitory activity on murine granulocytic colony formation of bone marrow cell-conditioned medium obtained from CSF-producing tumor-bearing nude mice. Cancer Res 44 : 3313-3316. 1984.

8) Motoyoshi $\mathrm{K}$ : Biological activities and clinical application of M-CSF. Int J Hematol 67 : 109-122, 1998.

9) Suzu S, et al : Identification of a high molecular weight macrophage colony-stimulating factor as a glycosaminoglycan-containing species. J Biol Chem 267 : $4345-$ 4348, 1992.

10) Suzu S, et al: Biological activity of a proteoglycan form of macrophage colony-stimulating factor and its binding to type V collagen. J Biol Chem 267 : 16812-16815, 1992.

11) Kimura F, et al: Structural analysis of proteoglycan macrophage colony-stimulating factor. J Biol Chem 269: 
19751-19756, 1994.

12) Ota J, et al : Association of $\mathrm{Cbl}$ with Fms and p85 in response to macrophage colony-stimulating factor. FEBS Letters $466: 96^{-1} 100,2000$.

13) Suzu S, et al : p56dok-2 as a cytokine-inducible inhibitor of cell proliferation and signal transduction. EMBO-J 19 : 5114-5122, 2000.

14) Suzu S, et al : Signal transduction in macrophages: negative regulation for macrophage colony-stimulating factor receptor signaling. Int J Hematol 76: 1-5, 2002.

15) Motoyoshi K, Takaku F : Serum cholesterol-lowering activity of human monocytic colony-stimulating factor. Lancet ii : 326-327, 1989.

16) Inoue $I$, et al : Macrophage colony-stimulating factor prevents the progression of atherosclerosis in Watanabe heritable hyperlipidemic rabbits. Atherosclerosis 93 : 322-329, 1992.

17) Suzu S, et al: Enhancing effect of human monocytic colony-stimulating factor on monocyte tumoricidal activity. Cancer Res $49: 5913-5917,1989$.

18) Suzu S, et al : Enhancement of the antibody-dependent tumoricidal activity of human monocytes by human monocytic colony-stimulating factor. Jpn J Cancer Res $81: 79-84,1990$.

19) Motoyoshi $K$, et al : Recombinant and native human urinary colony-stimulating factor directly augments $\mathrm{G}$ - and GM-CSF production of human peripheral blood monocytes. Exp Hematol $17: 68-71,1989$.

20) Hashimoto $\mathrm{S}$, et al : Macrophage colony-stimulating factor induces interleukin 8 production in human monocytes. Exp Hematol 24 : 123-128, 1996.

21) Sakurai $T$, et al: Effect of coadministration of M-CSF and IFN $\alpha$ on NK1.1 ${ }^{+}$cells in mice. J Interferon Cytokine Res 22 : 701-708, 2002.
22) Misawa $E$, et al : Booster effect of IL-2 on natural killer $1.1+$ cells stimulated by administration of macrophage colony-stimulating factor in mice. J Immunother $26: 21$ $30,2003$.

23) Saito $S$, et al:High serum macrophage colony-stimulating factor level during pregnancy. Int J Hematol 55 : 219-225, 1992.

24) Saito $S$, et al: Human macrophage colony-stimulating factor induces the differentiation of trophoblast. Growth Factors 9:11-19, 1993.

25) Masaoka $T$, et al : Double blind test of human urinary macrophage colony-stimulating factor for allogeneic and syngeneic bone marrow transplantation. $\mathrm{Br} \mathrm{J}$ Haematol $76: 501-505,1990$.

26) Ohno R, et al : Macrophage-colony stimulating factor reduces the incidence and duration of febrile neutropenia and shortens the period required to finish three courses of intensive consolidation therapy in acute myeloid leukemia : A double blind controlled study. J Clin Oncology $15: 2954-2965,1997$.

27) Mizutani $K$, et al: Clinical usefulness of macrophage colony-stimulating factor for ovalian cancers : Long-term prognosis after five years. Oncology Reports 10: 127-131, 2003.

28) Kimura F, et al : Augmentation of anti-tumor immunity using genetically M-CSFexpressing L 1210 cells. Exp Hematol $24: 360-363,1996$.

29) Suzu S, et al: Antitumor immunity induced by irradiated tumor cells producing macrophage colony-stimulating factor. Int J Hematol 73 : 378-382, 2001.

30) Morita $T$, et al : Tumor vaccination with macrophage colony-stimulating factor-producing Lewis lung carcinoma in mice. Blood 88 : 955-961, 1996. 